\title{
UNITED NATIONS ACTIVITIES WITH SPECIAL RELEVANCE TO ASIA 1991-1992
}

\author{
LEE SHIH-GUANG
}

\section{ADMISSION OF NEW MEMBERS TO THE UNITED NATIONS}

On 17 September 1991, the Democratic People's Republic of Korea and the Republic of Korea were admitted to the United Nations upon the recommendation of the Security Council, bringing total membership in the United Nations to 166 .

\section{AFGHANISTAN}

The General Assembly, inter alia, called upon all parties concerned to work urgently for the achievement of a comprehensive political solution, the cessation of hostilities and the creation of the necessary conditions for peace and normalcy that would enable the Afghan refugees to return voluntarily to their homeland in safety and honour; emphasized the need for an early start of the intra-Afghan dialogue for the establishment, through democratic procedures acceptable to the Afghan people, including free and fair elections, of a broad-based ground to ensure the broadest support and immediate participation of all segments of the Afghan people; requested the SecretaryGeneral and his Personal Representative to continue to encourage and facilitate the early realization of a comprehensive political settlement in Afghanistan in accordance with the provisions of the Geneva Agreements and of General Assembly resolution 46/23 (Report of the Secretary-General on the status of the process of political settlement, $A / 46 / 577-S / 23146$.) 


\section{CAMBODIA}

3.1. The Agreements on a Comprehensive Political Settlement of the Cambodia Conflict was signed on 23 October 1991, in Paris (S/23177), which was welcomed and supported by both the Security Council and the General Assembly. The Agreements provided, inter alia, for the designation of a Special Representative of the Secretary-General and the establishment of a United Nations Transitional Authority in Cambodia (UNTAC).

3.2. The Security Council called upon all Cambodian parties to comply fully with the ceasefire that entered into force upon signature of the Agreements, and the Supreme National Council of Cambodia, and all Cambodians for their part, to co-operate fully with the United Nations in the implementation of the Agreements as a comprehensive political settlement of the Cambodia conflict (SC resolution 718).

3.3. The General Assembly, inter alia, expressed support of the efforts of the Secretary-General to set up an effective UNTAC in Cambodia, with the aim of restoring peace and stability in Cambodia and to implement the Paris Agreements; called upon all parties concerned to ensure respect for and full observance of the human rights and fundamental freedoms of the Cambodian people to assist them to examine their right to self-determination in free and fair elections, as provided for in the Paris Agreements (resolution 46/18).

\section{INDIAN OCEAN AS A ZONE OF PEACE}

The General Assembly reiterated its decision to convene the first stage of a United Nations Conference at Colombo in 1993 as a necessary step for the implementation of the 1991 Declaration of the Indian Ocean as a Zone of Peace, which was adopted by a large majority but called for the full and effective participation in the Conference of the permanent members of the Security Council and the major maritime users of the Indian Ocean (resolution 46/49, adopted by a large majority, but France, Japan, United Kingdom and USA voted against the resolution).

\section{HUMAN RIGHTS}

\subsection{Afghanistan}

The General Assembly urged all parties concerned to increase the efforts in order to achieve a comprehensive political solution based on the five points of the Secretary-General's plan of 21 May 1991 on the free exercise of the right to self-determination by the people of Afghanistan through democratic procedures acceptable to the Afghan people, including free and fair 
elections, the cessation of hostilities and the creation of conditions that would permit the free return of refugees to their homeland in safety and honour, whenever they wish, and the full enjoyment of human rights and fundamental rights and freedoms by all Afghans; urged all parties to the conflict: (a) to respect accepted humanitarian rules as set out in the Geneva Conventions of 12 August 1949 and the additional protocols thereto of 1977; (b) to halt the use of weapons against the civilian population; (c) to protect all prisoners from acts of reprisals and violence, including cruel treatment, torture, and summary executions; (d) to transmit to the International Committee of the Red Cross the names of all prisoners; (e) to expedite the exchange of prisoners wherever they may be held; and (f) to grant to the ICRC unrestricted access to all parts of the country and the right to visit all prisoners in accordance with its established criteria; called upon all States and parties concerned to render all possible assistance in order to resolve the issue of all prisoners of war as a result of the conflict; requested the Afghan authorities to take the proper steps in order to permit activity by the political opponents; appealed to all conflicting parties to act likewise; urgently appealed to all member States, humanitarian organizations, and all parties concerned to co-operate fully, especially on the matter of mine detection and clearance in order to facilitate the return of refugees and displaced persons to their homes in safety and dignity; urged all parties concerned to undertake all necessary measures to insure the safety of personnel of humanitarian organizations involved in the implementation of United Nations humanitarian and economic assistance programs to Afghanistan (resolution 46/136).

\subsection{Iraq}

5.2.1. The General Assembly expressed its concern about the numerous allegations of grave human rights' violations by the Government of Iraq including arbitrary detention, extrajudicial killings, hostage-taking and the use of persons as 'human shields'; called upon the Government of Iraq to release all persons arrested and detained without ever being informed of charges against them, and without access to legal counsel or due process of law; called upon Iraq as a State Party to the International Covenant of Civil and Political Rights to abide by its obligations to that Covenant and the other international instruments of human rights, and particularly, to respect and ensure these rights to all individuals irrespective of their origin within its territory and subject to its jurisdiction, including Kurds and Shiites; called upon Iraq to reply quickly in a comprehensive and detailed manner to the allegations mentioned above (resolution 46/134).

5.2.2. The General Assembly requested Iraq to provide information on all Kuwaiti persons and third country nationals deported from Kuwait between 2 August 1990 and 26 February 1991 who may still be detained, and to release, in accordance with Iraq's obligations under Article 118 of the Geneva Convention relative to Prisoners of War and Article 134 of the Geneva Convention relative to the Protection of Civilian Persons in Times of War, these 
persons without delay; requested Iraq to provide, in accordance with its obligations under Articles 120 and 127 of the Geneva Convention relative to Prisoners of War and Articles 129 and 130 of the Geneva Convention relative to the Protection of Civilian Persons in Times of War, detailed information on persons arrested in Kuwait between 2 August 1990 and 26 February 1991 who may have died during or after that period while in detention as well as on the site of their graves; further requested Iraq to search for the persons still missing and to co-operate with the international humanitarian organizations such as the International Committee of the Red Cross in this regard (resolution 46/135).

\subsection{Myanmar}

The General Assembly reaffirmed that all Member States have an obligation to promote and protect fundamental freedoms stated in the Charter of the United Nations and elaborated in the Universal Declaration of Human Rights and the International Covenants on Human Rights and other applicable human rights' instruments; noted with concern the grave human rights situation in Myanmar; took note that the Government of Myanmar had assured the Assembly and the other United Nations bodies of its intention to take all necessary steps toward democracy in the light of elections held in 1990; looked forward to the early implementation of this commitment; urged the Government of Myanmar to allow all citizens to participate freely in the political process in accordance with the principles of the Universal Declaration of Human Rights (resolution 46/132).

\subsection{Covenants on Human Rights}

5.4.1. The Second Optional Protocol (abolition of the death penalty) to the International Covenant on Civil and Political Rights entered into force on 11 July $1991 .^{1}$

5.4.2. The General Assembly urged States Parties to the Covenants to fulfil their reporting obligations under the International Covenants on Human Rights; emphasized the importance of the strictest compliance by States Parties with their obligations under the Covenants and, where applicable, the Optional Protocols to the International Covenant on Civil and Political Rights; stressed the importance of avoiding the erosion of human rights by derogation from the instruments; and the necessity of strict observance of the agreed conditions and procedures for derogation under Article IV of the International Covenant of Civil and Political Rights, bearing in mind the need for States Parties to provide the fullest possible information during

1. Report of the Secretary-General A/46/393 which contained information on the status of the Covenants. 
states of emergency so that the justification for and appropriateness of measures taken in these circumstances could be assessed; appealed to States Parties of the Covenants that have exercised their sovereign rights to make reservations in accordance with relevant rules of international law to consider whether such reservations should be reviewed (resolution 46/113).

\subsection{Human Rights of Indigenous People}

The General Assembly adopted a program of activities to be taken at the national and international level, following the Assembly's decision to proclaim 1993 as the International Year for the World's Indigenous People (resolution $46 / 128)$.

\section{IRAQ INVASION OF KUWAIT: SUBSEQUENT DEVELOPMENT}

6.1. By its resolution 678 (1990) adopted on 29 November 1990, the Security Council authorized Member States co-operating with Kuwait's legitimate Government to use 'all necessary means' to compel Iraq to comply with all its relevant resolutions and to restore international peace and security in the area, if Iraq had not fully implemented such resolutions by 15 January 1991. Despite the diplomatic initiatives of a number of Member States and efforts by the Secretary-General (including his meeting with Iraqi President SADDAM HUSSEIN in Baghdad on 12 and 13 January 1991), Iraq continued its occupation of Kuwait. On 15 January 1991, the Secretary-General issued an appeal in which he urged Iraq to comply with the relevant Security Council resolutions beginning with resolution $660(1990)$ and thus to 'turn the course of events away from catastrophe'. On 16 January 1991, one day after the deadline, the States co-operating with the Government of Kuwait, acting in accordance with the Council's authorization, but not under the control of or direction by the United Nations, began offensive military operations. On 27 February, after six weeks of intensive air and ground action, Kuwait City was liberated. The same day, Iraq reported that all of its armed forces had withdrawn from Kuwait. Within hours it also informed the Security Council that it had decided to comply with Security Council resolution 660 (1990) and all other Security Council resolutions. Offensive operations were suspended as of midnight on 28 February 1991. From 2 March 1991 to 11 October 1991, the Security Council adopted 11 resolutions on the situation between Iraq and Kuwait.

6.2. By its resolution 686 of 2 March 1991,2 the Security Council, acting under Chapter VII of the Charter, demanded that Iraq implement its acceptance of all 12 resolutions adopted in 1990 and further demanded that Iraq:

2. Adopted by a vote of 11 in favour. 1 against (Cuba), and 3 abstentions (China, India and Yemen). 
(a) cease hostile or provocative actions by its forces against all Member States including missile attacks and flights of combat aircraft;

(b) designate military commanders to meet with counterparts from the forces of Kuwait and the Member States co-operating with Kuwait pursuant to resolution 678 to arrange for cessation of hostilities at the earliest possible time;

(c) arrange for immediate access to and release of all prisoners of war under the auspices of the International Committee of the Red Cross and return the remains of any deceased personnel of the forces of Kuwait and the Member States co-operating with Kuwait; and

(d) provide all information and assistance in identifying Iraqi mines, booby traps and other explosives as well as any chemical and biological weapons and material in Kuwait, in areas of Iraq where forces of Member States co-operating with Kuwait are present temporarily and in the adjacent waters.

6.3. Iraq informed the Secretary-General and the President of the Security Council on 3 March 1991, that it had agreed to fulfil its obligations under resolution 686. On 3 April, after more than one month of extensive consultations, the Security Council adopted resolution 687 (1991) setting specific terms for a formal ceasefire to end the conflict. ${ }^{3}$ Resolution 687 of 3 April 1991 reads as follows (in part):

\section{The Security Council,}

Recalling its resolutions 660 (1990) of 2 August 1990, 661 (1990) of 6 August 1990, 662 (1990) of 9 August 1990, 664 (1990) of 18 August 1990, 665 (1990) of 25 August 1990, 666 (1990) of 13 September 1990, 667 (1990) of 16 September 1990, 669 (1990) of 24 September 1990, 670 (1990) of 25 September 1990, 674 (1990) of 29 October 1990, 677 (1990) of 28 November 1990, 678 (1990) of 29 November 1990 and 686 (1991) of 2 March 1991.

Affirming the commitment of all Member States to the sovereignty, territorial integrity and political independence of Kuwait and Iraq, and noting the intention expressed by the Member States cooperating with Kuwait under paragraph 2 of resolution 678 (1990) to bring their military presence in Iraq to an end as soon as possible consistent with paragraph 8 of resolution 686 (1991).

Reaffirming the need to be assured of Iraq's peaceful intentions in the light of its unlawful invasion and occupation of Kuwait.

Bearing in mind its objective of restoring international peace and security in the area as set out in recent resolutions of the Security Council.

Conscious of the need to take the following measures acting under Chapter VII of the Charter.

1. Affirms all thirteen resolutions noted above, except as expressly changed below to achieve the goals of this resolution, including a formal cease-fire;

3. Adopted by a vote of 12 in favour, 1 against (Cuba) and 2 abstentions (Ecuador and Yemen). 
$(A)$

2. Demands that Iraq and Kuwait respect the inviolability of the international boundary and the allocation of islands set out in the "Agreed Minutes Between the State of Kuwait and the Republic of Iraq Regarding the Restoration of Friendly Relations, Recognition and Related Matters", signed by them in the exercise of their sovereignty of Baghdad on 4 October 1963 and registered with the United Nations and published by the United Nations in document 7063, United Nations, Treaty Series, 1964:

3. Calls upon the Secretary-General to lend his assistance to make arrangements with Iraq and Kuwait to demarcate the boundary between Iraq and Kuwait, drawing on appropriate material, including the map transmitted bySecurity Council document $\mathrm{S} / 22412$ and to report back to the Security Council within one month;

4. Decides to guarantee the inviolability of the above-mentioned international boundary and to take as appropriate all necessary measures to that end in accordance with the Charter of the United Nations;

(B)

5. Requests the Secretary-General, after consulting with Iraq and Kuwait, to submit within three days to the Security Council for its approval a plan for the immediate deployment of a United Nations observer unit to monitor the Khor Abdullah and a demilitarized zone, which is hereby established, extending ten kilometres into Iraq and five kilometres into Kuwait from the boundary referred to in the "Agreed Minutes Between the State of Kuwait and the Republic of Iraq Regarding the Restoration of Friendly Relations, Recognition and Related Matters" of 4 October 1963;

7. Invites Iraq to reaffirm unconditionally its obligations under the Geneva Protocol for the Prohibition of the Use in War of Asphyxiating. Poisonous or Other Gases, and of Bacteriological Methods of Warfare, signed at Geneva on 17 June 1925, and to ratify the Convention on the Prohibition of the Development, Production and Stockpiling of Bacteriological (Biological) and Toxin Weapons and on Their Destruction, of 10 April 1972;

8. Decides that Iraq shall unconditionally accept the destruction, removal, or rendering harmless, under international supervision, of:

(a) All chemical and biological weapons and all stocks of agents and all related subsystems and components and all research, development, support and manufacturing facilities;

(b) All ballistic missiles with a range greater than 150 kilometres and related major parts, and repair and production facilities;

9. Decides, for the implementation of paragraph 8 above, the following:

(a) Iraq shall submit to the Secretary-General, within fifteen days of the adoption of the present resolution, a declaration of the locations, amounts and types of all items specified in paragraph 8 and agree to urgent, on-site inspection as specified below: 
(b) The Secretary-General, in consultation with the appropriate Governments and, where appropriate, with the Director-General of the World Health Organization, within forty-five days of the passage of the present resolution, shall develop, and submit to the Council for approval, a plan calling for the completion of the following acts within forty-five days of such approval:

(i) The forming of a Special Commission, which shall carry out immediate onsite inspection of Iraq's biological, chemical and missile capabilities, based on Iraq's declarations and the designation of any additional locations by the Special Commission itself;

(ii) The yielding by Iraq of possession to the Special Commission for destruction, removal or rendering harmless, taking into account the requirements of public safety, of all items specified under paragraph 8 (a) above, including items at the additional locations designated by the Special Commission under paragraph 9 (b) (i) above and the destruction by Iraq, under the supervision of the Special Commission, of all its missile capabilities, including launchers, as specified under paragraph 8 (b) above;

(iii) The provision by the Special Commission of the assistance and cooperation to the Director-General of the International Atomic Energy Agency required in paragraphs 12 and 13 below;

10. Decides that Iraq shall unconditionally undertake not to use, develop, construct or acquire any of the items specified in paragraphs 8 and 9 above and requests the Secretary-General, in consultation with the Special Commission, to develop a plan for the future ongoing monitoring and verification of Iraq's compliance with this paragraph, to be submitted to the Security Council for approval within one hundred and twenty days of the passage of this resolution;

11. Invites Iraq to reaffirm unconditionally its obligations under the Treaty on the Non-Proliferation of Nuclear Weapons of 1 July 1968;

12. Decides that Iraq shall unconditionally agree not to acquire or develop nuclear weapons or nuclear-weapons-usable material or any subsystems or components or any research, development, support or manufacturing facilities related to the above; to submit to the Secretary-General and the Director-General of the International Atomic Energy Agency within fifteen days of the adoption of the present resolution a declaration of the locations, amounts, and types of all items specified above; to place all of its nuclear-weapons-usable materials under the exclusive control, for custody and removal, of the International Atomic Energy Agency, with the assistance and cooperation of the Special Commission as provided for in the plan of the SecretaryGeneral discussed in paragraph 9 (b) above; to accept, in accordance with the arrangements provided for in paragraph 13 below, urgent on-site inspection and the destruction, removal or rendering harmless as appropriate of all items specified above; and to accept the plan discussed in paragraph 13 below for the future ongoing monitoring and verification of its compliance with these undertakings;

13. Requests the Director-General of the International Atomic Energy Agency, through the Secretary-General, with the assistance and cooperation of the Special Commission as provided for in the plan of the Secretary-General in paragraph 9 (b) above, to carry out immediate on-site inspection of Iraq's nuclear capabilities based on Iraq's declarations and the designation of any additional locations by the Special 
Commission; to develop a plan for submission to the Security Council within fortyfive days calling for the destruction, removal, or rendering harmless as appropriate of all items listed in paragraph 12 above; to carry out the plan within forty-five days following approval by the Security Council; and to develop a plan, taking into account the rights and obligations of Iraq under the Treaty on the Non-Proliferation of Nuclear Weapons of 1 July 1968, for the future ongoing monitoring and verification of Iraq's compliance with paragraph 12 above, including an inventory of all nuclear material in Iraq subject to the Agency's verification and inspections to confirm that Agency safeguards cover all relevant nuclear activities in Iraq, to be submitted to the Security Council for approval within one hundred and twenty days of the passage of the present resolution;

14. Takes note that the actions to be taken by Iraq in paragraphs $8,9,10,11,12$ and 13 of the present resolution represent steps towards the goal of establishing in the Middle East a zone free from weapons of mass destruction and all missiles for their delivery and the objective of a global ban on chemical weapons;

(D)

15. Requests the Secretary-General to report to the Security Council on the steps taken to facilitate the return of all Kuwaiti property seized by Iraq, including a list of any property that Kuwait claims has not been returned or which has not been returned intact;

16. Reaffirms that Iraq, without prejudice to the debts and obligations of Iraq arising prior to 2 August 1990, which will be addressed through the normal mechanisms, is liable under international law for any direct loss, damage, including environmental damage and the depletion of natural resources, or injury to foreign Governments, nationals and corporations, as a result of Iraq's unlawful invasion and occupation of Kuwait;

17. Decides that all Iraqi statements made since 2 August 1990 repudiating its foreign debt are null and void, and demands that Iraq adhere scrupulously to all of its obligations concerning servicing and repayment of its foreign debt;

18. Decides also to create a fund to pay compensation for claims that fall within paragraph 16 above and to establish a Commission that will administer the fund;

19. Directs the Secretary-General to develop and present to the Security Council for decision, no later than thirty days following the adoption of the present resolution, recommendations for the fund to meet the requirement for the payment of claims established in accordance with paragraph 18 above and for a programme to implement the decisions in paragraphs 16,17 and 18 above, including: administration of the fund; mechanisms for determining the appropriate level of Iraq's contribution to the fund based on a percentage of the value of the exports of petroleum and petroleum products from Iraq not to exceed a figure to be suggested to the Council by the Secretary-General, taking into account the requirements of the people of Iraq, Iraq's payment capacity as assessed in conjunction with the international financial institutions taking into consideration external debt service, and the needs of the Iraqi economy; arrangements for ensuring that payments are made to the fund; the process by which funds will be allocated and claims paid; appropriate procedures 
for evaluating losses, listing claims and verifying their validity and resolving disputed claims in respect of Iraq's liability as specified in paragraph 16 above; and the composition of the Commission designated above:

(F)

20. Decides, effective immediately, that the prohibitions against the sale or supply to Iraq of commodities or products, other than medicine and health supplies, and prohibitions against financial transactions related thereto contained in resolution 661 (1990) shall not apply to foodstuffs notified to the Security Council Committee established by resolution 661 (1990) concerning the situation between Iraq and Kuwait or, with the approval of that Committee, under the simplified and accelerated "no-objection" procedure, to materials and supplies for essential civilian needs as identified in the report of the Secretary-General dated 20 March 1991 [S/22366] and in any further findings of humanitarian need by the Committee:

21. Decides that the Security Council shall review the provisions of paragraph 20 above every sixty days in the light of the policies and practices of the Government of Iraq, including the implementation of all relevant resolutions of the Security Council, for the purpose of determining whether to reduce or lift the prohibitions referred to therein;

22. Decides that upon the approval by the Security Council of the programme called for in paragraph 19 above and upon Council agreement that Iraq has completed all actions contemplated in paragraphs $8,9,10,11,12$ and 13 above, the prohibitions against the import of commodities and products originating in Iraq and the prohibitions against financial transactions related thereto contained in resolution 661 (1990) shall have no further force or effect;

23. Decides that, pending action by the Security Council under paragraph 22 above, the Security Council Committee established by resolution 661 (1990) shall be empowered to approve, when required to assure adequate financial resources on the part of Iraq to carry out the activities under paragraph 20 above, exceptions to the prohibition against the import of commodities and products originating in Iraq;

24. Decides that, in accordance with resolution 661 (1990) and subsequent related resolutions and until a further decision is taken by the Security Council, all States shall continue to prevent the sale or supply, or the promotion or facilitation of such sale or supply, to Iraq by their nationals, or from their territories or using their flag vessels or aircraft, of:

(a) Arms and related matériel of all types, specifically including the sale or transfer through other means of all forms of conventional military equipment, including for paramilitary forces, and spare parts and components and their means of production, for such equipment;

(b) Items specified and defined in paragraphs 8 and 12 above not otherwise covered above;

(c) Technology under licensing or other transfer arrangements used in the production, utilization or stockpiling of items specified in subparagraphs (a) and (b) above;

(d) Personnel or materials for training or technical support services relating to the design, development, manufacture, use, maintenance or support of items specified in subparagraphs (a) and (b) above; 
25. Calls upon all States and international organizations to act strictly in accordance with paragraph 24 above, notwithstanding the existence of any contracts, agreements, licences or any other arrangements;

26. Requests the Secretary-General, in consultation with appropriate Governments, to develop within sixty days, for the approval of the Security Council, guidelines to facilitate full international implementation of paragraphs 24 and 25 above and paragraph 27 below, and to make them available to all States and to establish a procedure for updating these guidelines periodically;

27. Calls upon all States to maintain such national controls and procedures and to take such other actions consistent with the guidelines to be established by the Security Council under paragraph 26 above as may be necessary to ensure compliance with the terms of paragraph 24 above, and calls upon international organizations to take all appropriate steps to assist in ensuring such full compliance;

28. Agrees to review its decisions in paragraphs 22, 23, 24 and 25 above, except for the items specified and defined in paragraphs 8 and 12 above, on a regular basis and in any case one hundred and twenty days following passage of the present resolution, taking into account Iraq's compliance with the resolution and general progress towards the control of armaments in the region;

29. Decides that all States, including Iraq, shall take the necessary measures to ensure that no claim shall lie at the instance of the Government of Iraq, or of any person or body in Iraq, or of any person claiming through or for the benefit of any such person or body, in connection with any contract or other transaction where its performance was affected by reason of the measures taken by the Security Council in resolution 661 (1990) and related resolutions;

30. Decides that, in furtherance of its commitment to facilitate the repatriation of all Kuwaiti and third country nationals, Iraq shall extend all necessary cooperation to the International Committee of the Red Cross, providing lists of such persons, facilitating the access of the International Committee of the Red Cross to all such persons wherever located or detained and facilitating the search by the International Committee of the Red Cross for those Kuwaiti and third country nationals still unaccounted for;

31. Invites the International Committee of the Red Cross to keep the SecretaryGeneral appraised as appropriate of all activities undertaken in connection with facilitating the repatriation or return of all Kuwaiti and third country nationals or their remains present in Iraq on or after 2 August 1990;

32. Requires Iraq to inform the Security Council that it will not commit or support any act of international terrorism or allow any organization directed towards commission of such acts to operate within its territory and to condemn unequivocally and renounce all acts, methods and practices of terrorism;

33. Declares that, upon official notification by Iraq to the Secretary-General and to 
the Security Council of its acceptance of the provisions above, a formal cease-fire is effective between Iraq and Kuwait and the Member States cooperating with Kuwait in accordance with resolution 678 (1990);

34. Decides to remain seized of the matter and to take such further steps as may be required for the implementation of the present resolution and to secure peace and security in the area.

6.4. The Security Council, inter alia, declared that a formal ceasefire between Iraq, Kuwait and the countries co-operating with Kuwait would come into effect after official notification by Iraq of its acceptance of the conditions of resolution 687. On 6 April, Iraq officially notified the SecretaryGeneral and the President of the Security Council that it had no choice but to accept the provisions of resolution 687. On 11 April, the President of the Security Council, on behalf of its members, formally accepted Iraq's notification. He noted that the conditions established in the resolution had been met and that the formal ceasefire was in effect.

6.5. Pursuant to resolution 687, the following bodies, were to be established:

(a) The United Nations Iraq-Kuwait Observation Mission (UNIKOM): to monitor the Khawr Abd Allah Waterway between Iraq and Kuwait and the demilitarized zone extending 10 kilometres into Iraq and five kilometres into Kuwait, to deter violations of boundary through its presence in and surveillance of the demilitarized zone (DMZ), and to observe any hostile or potentially hostile action mounted from the territory of one State to the other;

(b) the United Nations Special Commission to oversee the destruction, removal or rendering harmless of all Iraq's chemical and biological weapons and related capabilities and facilities, and its ballistic missiles with a range greater than 150 kilometres. The Commission is also to assist the International Atomic Energy Agency in the destruction, removal or rendering harmless as appropriate of Iraq's nuclear capabilities;

(c) the Iraq-Kuwait Boundary Demarcation Commission: to demarcate the international boundary set out in the 'agreed minutes between the State of Kuwait and the Republic of Iraq regarding the restoration of friendly relations, recognition and related matters', signed by them on 4 October 1963 and registered with the United Nations;

(d) the United Nations Compensation Commission: to administer the Compensation Fund, to pay compensation for 'any direct loss, damage, including environmental damage, and the depletion of natural resources, or injury to foreign Governments, nationals and corporations, as a result of Iraq's unlawful invasion and occupation of Kuwait'.

6.6 Pursuant to Security Council resolution 686 (1991), the Secretary-General appointed a senior United Nations official to co-ordinate the return of property from Iraq to Kuwait.

6.7. In addition, the Security Council's Sanctions Committee established by resolution 661 is to monitor the prohibitions against the sale or supply of 
arms to Iraq and the related sanctions set out in resolution 687 in accordance with the approved guidelines. Furthermore, in pursuance of resolutions 706 and 712, the Sanctions Committee is responsible for monitoring the export by Iraq of petroleum and petroleum products during a period of six months beginning on 19 September 1991 to produce a sum not to exceed \$1.6 billion for the purchase of items of a humanitarian character. The Committee is also responsible for monitoring the purchase of those items by Iraq and their distribution inside the country.

6.8. By its resolution 689,4 the Security Council, acting under Chapter VII of the Charter, approved the Report of the Secretary-General on the implementation of paragraph 5 of Security Council resolution 687 (S/22454 and Addenda 1,2,3) and established UNIKOM; noted that the decision to set up UNIKOM was taken in accordance with paragraph 5 of resolution 687 and can only be terminated by a decision of the Council. The Council decided to review the situation every six months.

6.9. By its resolution 692,5 the Security Council decided to establish the Compensation Fund and a Commission to administer the Fund (S/22559) under a Governing Council to be located in Geneva. The Security Council requested the Governing Council to report as soon as possible on the actions it had taken with regard to the mechanisms for determining the appropriate level of Iraq's contribution to the Fund and the arrangements for ensuring that payments are made to the Fund.

6.10. By its resolution 699,6 the Security Council, acting again under Chapter VII of the Charter, approved the plan contained in the Report of the SecretaryGeneral (S/22614) regarding the disposal of weapons, facilities and all other items specified in Section C of resolution 687, and confirmed that the Special Commission and IAEA have the authority to conduct activities under Section $\mathrm{C}$ of resolution 687 for the purpose of the destruction, removal or rendering harmless of the items specified in paragraphs 8 and 12 of that resolution, after the 45-day period following the approval of this plan until such activities have been completed. It also decided that the Government of Iraq shall be liable for the full costs of carrying out the tasks authorized by Section $\mathrm{C}$ of resolution 687 .

6.11. By its resolution $700,{ }^{7}$ the Security Council approved the Guidelines to facilitate full international implementation of the arms embargo against Iraq required under its resolution 687 (S/22660). The Sanctions Committee established under resolution 661 was entrusted with the responsibility for the implementation of the Guidelines.

4. Adopted on 9 April 1991 by unanimous vote.

5. Adopted on 20 May 1991 by a vote of 14 in favour, none against, 1 abstention (Cuba).

6. Adopted on 17 June 1991 by unanimous vote.

7. Adopted on 17 June 1991 by unanimous vote. 
6.12. By its resolution $705,{ }^{8}$ the Security Council decided that compensation to be paid by Iraq (as arising from Section $E$ of resolution 687) shall not exceed 30 per cent of the annual value of its exports of petroleum and petroleum products $(\mathrm{S} / 22661)$.

6.13. By its resolution $706,{ }^{9}$ the Security Council decided, under Chapter VII of the UN Charter, the terms for the limited sale of Iraqi oil and oil products, for the purpose, inter alia, of meeting essential civilian needs under strict and close UN monitoring, and for the establishment by the United Nations of an escrow account to be administered by the Secretary-General.

6.14. By its resolution $707,,^{10}$ the Security Council condemned Iraq's 'serious violation' of a number of its obligations under Section C of resolution 687 (i.e. destruction of weapons) and of its undertakings to co-operate with the Special Commission and IAEA. The Council adopted a list of nine demands to Iraq.

6.15. By its resolution $712,{ }^{11}$ the Security Council confirmed the ceiling of $\$ 1.6$ billion in limited Iraqi oil sale established by the Council in resolution 706, and invited its Sanctions Committee to authorize the Secretary-General to release immediate one-third of that asset from an escrow amount established by the United Nations to meet Iraq's essential civilian needs.

6.16. By its resolution $715,{ }^{12}$ the Security Council demanded that Iraq meet unconditionally all its obligations under two plans approved by the Council for the future monitoring and the verification of Iraq's compliance with resolution 687 and 707 .

\section{LAW OF THE SEA}

7.1 As of 12 December 1991, fifty-one States had ratified the 1982 UN Convention on the Law of the Sea, sixty ratifications are required to bring the Convention into force.

7.2. In 1991, the Preparatory Commission of the International Sea-bed Authority and the International Tribunal for the Law of the Sea approved two applications for registration as pioneer investors, i.e. China Ocean Mineral Resources Research and Development Association (COMRA) and the Interoceanmetal Joint Organization (IOM) submitted by Bulgaria, Cuba, the Czech and Slovak Federal Republic, Poland and the USSR. In 1987, the Preparatory Commission had already registered as pioneer investors: the

8. Adopted on 15 August 1991 by unanimous vote.

9. Adopted on 15 August 1991 by a vote of 13 in favour, 1 against (Cuba), and 1 abstention (Yemen).

10. Adopted on 15 August 1991 by unanimous vote.

11. Adopted on 19 September 1991 by a vote of 13 in favour, 1 against (Cuba), and 1 abstention (Yemen).

12. Adopted on 11 October 1991 by unanimous vote. 
Institut français de recherche pour l'exploitation de la mer (IFREMER), the Government of India Deep Ocean Research Development Co. Ltd. (DORD) and Yuzhmorgeologiya, whose applications were submitted respectively by the Governments of France, India and the USSR, respectively. A total of six pioneer investors have then been registered (see $A / 46$ / 724, paras. 146-151).

7.3. The Secretary-General's initiative to promote dialogue aimed at addressing issues of concern to some States in order to achieve universal participation in the Convention continued in 1991, and in its course the following issues relating to the regime for sea-bed mining, as contained in Part XI of the 1982 LOS Convention, were identified as problem areas for some States: costs to States parties, the Enterprise, transfer of technology, production limitations, compensation fund, financial terms for contracts, decisionmaking, environmental considerations, and the Review Conference (Report of the Secretary-General, $\mathrm{A} / 46 / 724$, paragraphs $15-20$ ).

7.4. The 1989 Treaty on the Zone of Co-operation in an Area between the Indonesian province of East Timor and Northern Australia ("Timor-Gap Treaty") entered into force on 11 February 1991 (A/45/721, para. 26). On 22 February 1991, Portugal submitted an application to the International Court of Justice against Australia regarding certain actions undertaken by that country relating to East Timor concerning the so-called Timor-Gap. The Application focused mainly on the 'opposability to Australia of the right of the people of East Timor to self-determination and of Portugal's capacity as the administering power of that non-self-governing Territory'. Through that Application, Australia's international responsibility was claimed. Portugal specifically requested that Australia cease its efforts with Indonesia concerning delimitation and resource development, and generally refrain from exercising jurisdiction over the continental shelf in the area of the Timor-Gap.

\section{FISHERIES}

The General Assembly called upon all members of the international community to implement its resolutions 44/225 and 45/197 (see 1 ASYIL 249) by, inter alia, taking the following actions:

(a) beginning on 1 January 1992, reducing fishing effort in existing largescale pelagic drift-net fishing by, inter alia, reducing the number of vessels involved, the lengths of the nets and the area of operation so as to achieve by 30 June 1992 a 50 per cent reduction in fishing effort;

(b) continuing to ensure that the areas of operation of large-scale pelagic high seas drift-net fishing were not expended and, beginning on 1 January 1992, were further reduced in accordance with the above paragraph;

(c) ensure that a global moratorium on all large-scale pelagic drift-net fishing is fully implemented on the high seas of the world's oceans and seas, including enclosed seas and semi-enclosed seas by 31 December 1992 (resolution 46/215 and Report of the Secretary-General, A/46/645/Add. 6 and A/46/344, Annex). 


\section{ILLICIT TRAFFIC IN NARCOTIC DRUGS AND PSYCHOTROPIC SUBSTANCES}

The General Assembly affirmed that the fight against drug abuse and illicit trafficking should continue to be based on strict respect for the principles enshrined in the Charter of the United Nations and international law, particularly respect for the sovereignty and the territorial integrity of States, non-interference in the internal affairs of States, and non-use of force or the threat of force in international relations; called upon all States to intensify their actions to promote effective co-operation in the effort to combat drug abuse and illicit trafficking so as to contribute to a climate conducive to achieving this end, and to refrain from using the issue for political purposes; further affirmed that the international fight against drug trafficking should not in any way justify violation of the principles enshrined in the Charter and international law, particularly the right of all peoples freely to determine without external interference their political status and to pursue their economic, social and cultural development, and that every state has the duty to respect this right in accordance with the provisions of the Charter (resolution 46/101).

\section{INTERNATIONAL TERRORISM}

10.1. The General Assembly urged all States to fulfil their obligations under international law and take effective and resolute measures for the speedy and the final elimination of international terrorism, and to that end, in particular:

(a) to prevent the preparation and organization in their respective territories, for commission within or outside their territories, of terrorists and subversive acts directed against other States and their citizens;

(b) to ensure the apprehension and prosecution or extradition of perpetrators of terrorist acts;

(c) to endeavour to conclude special agreements to that effect on a bilateral, regional and multilateral basis;

(d) to co-operate with one another in exchanging relevant information concerning the prevention and combating of terrorism;

(e) to take promptly all steps necessary to implement the existing international conventions on the subject to which they are parties, including the harmonization of their domestic legislation with those conventions.

10.2. All States as well as the relevant $\mathrm{UN}$ organs were urged by the General Assembly to contribute to the progressive elimination of the causes underlying international terrorism and to pay special attention to all situations including colonialism, racism and situations involving mass and flagrant violations of human rights and fundamental freedom that may give rise to international terrorism and may endanger international peace and security; at the same time, the General Assembly also expressed concern at the growing and dangerous links between terrorist groups, drug traffickers and their 
para-military gangs which have resulted to all types of violence thus endangering the constitutional order of States and violating basic human rights (resolution 46/51).

\section{ANTARCTICA}

11.1. At its 11th Antarctic Treaty Special Consultative Meeting, a Protocol on Environmental Protection to the Antarctic Treaty (including four annexes) was adopted on 4 October 1991. The Protocol designates Antarctica as a 'natural reserve, devoted to peace and science' and sets forth the general principles applicable to any human activity in Antarctica. All mineral-resource activities, except scientific activities, are prohibited under the Protocol.

11.2. The General Assembly once again expressed its regret that, despite the numerous resolutions adopted by it, the Secretary-General had not been invited to the meetings of the Antarctic Treaty Consultative Parties, and urged once again that the Secretary-General be invited to their future meetings; reiterated its call upon the Antarctic Treaty Consultative Parties to deposit information and documents covering all aspects of Antarctica with the Secretary-General of the United Nations; disappointed that, while welcoming the signing of the Madrid Protocol on Environmental Protection by the Antarctic Treaty Parties, the Protocol was not negotiated with the full participation of the international community, and the protocol lacked the monitoring and implementation mechanisms for compliance and had not taken into consideration the call of the international community to ban permanently prospecting and mining in Antarctica (resolution 46/41 $\mathrm{A}^{13}$ ).

\section{NON-SELF GOVERNING TERRITORIES}

\section{(a) American Samoa}

The General Assembly welcomed the measures taken by the territorial government in 1990 to implement the American Samoa Environmental Act by protecting and conserving marine resources and by preventing the pollution of its territorial waters; called upon the United States in co-operation with the territorial government to promote the economic and social development in the territory (resolution $46 / 68 B$ ).

\section{(b) Guam}

The General Assembly called upon the Administering Power to ensure that the presence of military bases and installations in the territory should

13. Adopted by a roll-call vote of 101-0-7 with 53 States not participating in the vote. 
not constitute an obstacle to the implementation of the Declaration on the Granting of Independence to Colonial Countries and Peoples nor hinder the population of the territory from exercising its right to self-determination and independence in conformity with the purposes and principles of the Charter of the United Nations; urged the United States to support measures by the territorial government aimed at promoting growth in commercial fishing and agriculture (resolution 46/68B VI).

\section{(c) Tokelau}

The General Assembly encouraged the Government of New Zealand to continue to respect fully the wishes of the people of Tokelau in carrying out the territory's political and economic development in order to preserve their social, cultural and the traditional heritage (resolution 46/68B VIII).

\section{UNITED NATIONS DECADE OF INTERNATIONAL LAW}

The Sixth Committee reconvened the Working Group at the Forty-Sixth session to continue its work in accordance with resolution $47 / 40$ on this subject. The General Assembly, inter alia, invited all States and international organizations and institutions referred to in the programme to provide, update or supplement information on activities they had undertaken in the implementation of the programme to the Secretary-General, as well as to submit their views on possible activities for the next term of the Decade; requested the Secretary-General to submit on the basis of such information a report to the General Assembly at its Forty-Seventh session; encouraged States to disseminate information contained in the Report of the SecretaryGeneral (A/46/372) at the national level (resolution 46/53).

\section{THE INTERNATIONAL LAW COMMISSION}

13.1. The International Law Commission held its Forty-Third session at the UN Office at Geneva from 29 April to 19 July 1991.

13.2. It completed the final draft articles on jurisdictional immunities of States and their property and the provisional draft articles on the Law of the Non-Navigational Uses of International Watercourses and on the Draft Code of Crimes against the Peace and Security of Mankind (Report of the International Law Commission on the Work of its Forty-Third session, Official Records of the General Assembly, Forty-Sixth session, Supplement no. 10 (A/46/10).

13.3 The General Assembly suggested a number of measures to improve the Commission's procedures and methods of work (resolution 46/54).

13.4. The General Assembly drew the attention of Governments to the 
importance, for the International Law Commission, to have their views on the subject-matters mentioned in paragraph 13.2 above and urged Governments to present in writing their comments and observations to the Commission (resolution 46/54).

\section{INTERNATIONAL CRIMINAL JURISDICTION}

The General Assembly invited the International Law Commission within the framework of the Draft Code of Crimes against the Peace and Security of Mankind to consider further and analyze issues raised in its 1990 Report (A/46/10, Ch. II, Sec C) concerning the question of international criminal jurisdiction including proposals for the establishment of an international criminal court or other international criminal trial mechanism in order to enable the General Assembly to provide guidance on the matter (see resolution 46/54).

\section{JURISDICTIONAL IMMUNITIES OF STATES AND THEIR PROPERTY}

15.1. The International Law Commission decided at its Forty-Third session to recommend that the General Assembly should convene an international conference of plenipotentiaries to examine the draft articles on jurisdictional immunities of States and their properties prepared by it and to conclude a convention on the subject (paragraph 25, Report of the International Law Commission, A/46/10).

15.2. Divergent views were expressed on the draft articles at the Sixth Committee. The General Assembly decided to invite States to submit their written comments and observations on the Draft Articles and to establish at its FortySeventh session an open-ended working group of the Sixth Committee to examine, in the light of the written comments of Governments as well as views expressed in debates at the Forty-Sixth session of the Assembly:

(a) issues of substance arising out of the Draft Articles in order to facilitate a successful conclusion of a convention through the promotion of a general agreement:

(b) the question of convening an international conference to be held in 1994, or subsequently, to conclude a convention on jurisdictional immunities of States and their property (resolution 46/55, paragraph 4).

\section{SPECIAL COMMITTEE ON THE CHARTER OF THE UNITED NATIONS AND ON THE STRENGTHENING OF THE ROLE OF THE ORGANIZATION (THE CHARTER COMMITTEE)}

16.1. The Charter Committee held its 1991 session from 4 to 22 February 
1991 in New York (Official Records of the General Assembly, Forty-Sixth session, Supplement No. 33 and Corr. (A/46/33 and Corr.1) and completed its work on the draft Declaration on Fact-Finding by the United Nations in the field of Maintenance of International Peace and Security.

16.2. The USSR submitted a working paper entitled 'New Issues for consideration in the Special Committee' (A/AC.182/L.65), which included the question of co-operation between the United Nations and Regional Organizations.

16.3. The General Assembly requested the Charter Committee at its 1992 session to consider the following:

(a) to accord priority to the question of the maintenance of international peace and security in all its aspects and to consider the proposal on the enhancement of co-operation between the $U N$ and the regional organizations as well as other specific proposals in this regard that may be submitted;

(b) to continue its work on the question of the peaceful settlement of disputes between States and, in this context, to consider the proposal on UN Rules for the Conciliation of Disputes between States and to consider other specific proposals relating to this question that may be submitted to the Committee at its 1992 session;

(c) to consider various proposals with the aim of strengthening the role of the Organization and enhancing its effectiveness.

16.4. The General Assembly decided that the Charter Committee accept the participation of observers of Member States in its meetings, including those of its Working Group (resolution 46/58).

\section{HANDBOOK ON THE PEACEFUL SETTLEMENT OF DISPUTES BETWEEN STATES}

In response to a request of the General Assembly, the Secretary-General completed in 1991 the preparation of the Handbook on the Peaceful Settlement of Disputes between States (UN Pub. Sales No. E. 92). The publication contains four chapters with an introduction and three annexes plus bibliography and index: Chapter I, Principles of the Peaceful Settlement of Disputes between States; Chapter II, Means of Settlement, which includes negotiations, consultations, inquiry, good offices, mediation, conciliation, arbitration, judicial settlement, resort to regional agencies or arrangements and other peaceful means; Chapter III, Procedures Envisaged in the Charter of the United Nations; Chapter IV Procedures Envisaged in Other International Instruments.

\section{DECLARATION ON FACT-FINDING}

18.1. The General Assembly at its Forty-Sixth session adopted the Declaration on Fact-Finding by the United Nations in the Field of Maintenance 
of International Peace and Security, which was prepared by the Charter Committee; was convinced that the adoption of the Declaration would contribute to strengthening the role of the United Nations and enhancing its effectiveness in maintaining international peace and security; urged that all efforts be made so that the Declaration becomes generally known and fully implemented. The text of the Declaration is annexed to General Assembly resolution $46 / 59$.

18.2. Main points of the Declaration are summarized as follows: fact-finding means any activity designed to obtain detailed knowledge of the relevant facts of any dispute or situation which the competent UN organs need in order to exercise effectively their functions in relation to the maintenance of international peace and security. Fact-finding should be comprehensive, objective, impartial and timely. The sending of a fact-finding mission can signal the concerns of the organization and should therefore contribute to building confidence and diffusing the dispute or situation while avoiding any aggravation of it. The sending of a UN fact-finding mission to the territory of any State requires the prior consent of the State, subject to the relevant provisions of the Charter of the United Nations. Fact-finding missions may be undertaken by the Security Council, the General Assembly and the Secretary-General in the context of their respective responsibilities in maintaining international peace and security in accordance with the Charter. The Secretary-General, on his own initiative or at the request of the States concerned, should consider undertaking a fact-finding mission when a dispute or situation exists. The Secretary-General should monitor the state of international peace and security regularly and systematically in order to provide early warning of disputes or situations which might threaten international peace and security. The Secretary-General may bring relevant information to the attention of the Security Council and, where appropriate, of the General Assembly. To this end, the Secretary-General should make full use of the information-gathering capabilities of the Secretariat and keep under review the improvement of these capabilities.

\section{INTERNATIONAL TRADE LAW}

19.1. The United Nations Commission on International Trade Law (UNCITRAL) held its Twenty-Fourth session in 1991.14 The General Assembly called upon UNCITRAL to continue to take into account, as appropriate, the relevant provisions of the resolutions concerning the international economic order; affirmed the importance, in particular, for developing countries, of the work of UNCITRAL concerned with training and assistance in the field of international trade law and the desirability for it to sponsor seminars and symposia to provide such training and assistance (resolution $46 / 56)$.

14. Report of the Commission, A/46/17 and Corr. 1 . 
19.2. The United Nations Conference on the Liability of Operators of Transport Terminals in International Trade was held at Vienna in April 1991 and resulted in the adoption of the UN Convention on the Liability of Operators of Transport Terminals in International Trade. ${ }^{15}$ The Convention was based on work prepared by UNCITRAL.

19.3. At its Twenty-Fourth session, UNCITRAL decided to organize, as a first step in the preparation of its programme of activities for the United Nations Decade of International Law, a Congress on International Trade Law during the last week of its Twenty-Fifth session to be held in New York from 4 to 22 May $1992 .{ }^{16}$

19.4. The General Assembly expressed the hope that all States and interested international organizations would take the opportunity to send appropriate delegates to the Congress to consider the accomplishments achieved in the progressive unification and harmonization of international trade law during the past 25 years and the practical needs that can be foreseen in the future (resolution 46/56).

\section{MEASURES TO AMEND THE NUCLEAR WEAPON TESTS BAN TREATY IN THE ATMOSPHERE, IN OUTER SPACE AND UNDER WATER}

A substantive session of the Amendment Conference of the States Parties to the Treaty Banning Nuclear Weapon Tests in the Atmosphere, in Outer Space and Under Water was held in New York in January 1991. ${ }^{17}$ This Conference was held at the request of more than one-third of the parties to the Treaty; they had requested the Depositary Governments to convene a conference to consider an amendment that would convert the Treaty into a comprehensive test-ban treaty. Pursuant to a decision of the Amendment Conference, the President was to conduct consultations with a view to achieving progress on such issues as verification of compliance and possible sanctions against non-compliance. The General Assembly of the United Nations reiterated its conviction that, pending the conclusion of a comprehensive nuclear-test-ban treaty, the nuclear-weapon States should suspend all nuclear-test explosives through an agreed moratorium or unilateral moratoria (resolution 46/28, US and UK voted against the resolution).

15. A/CONF.152/13.

16. Report of the International Trade Law Commission A/46/17 and Corr. 1.

17. Report of the Conference, PTBT/CONF/131 Rev. 1. 


\section{TRANSPARENCY IN ARMAMENTS}

By its Resolution 46/36L, the General Assembly requested the SecretaryGeneral to establish and maintain at the UN headquarters in New York a universal and non-discriminatory Register of Conventional Arms to include data on international arms transfers as well as information provided by Member States on military holdings, procurement through national production and relevant policies. The procedures and input requirements were set out in an Annex to the resolution. The Register came into effect on 1 January 1992. The Secretary-General was also requested to provide annually a consolidated report to the General Assembly of the data registered together with an index of the other inter-related information. 